\title{
Loop-mediated isothermal amplification: a rapid molecular technique for early diagnosis of Pseudomonas syringae pv. syringae of stone fruits
}

\author{
R. Goudarzi ${ }^{1}$ and M. M. Mortazavi $2,3,4^{*}$
}

\begin{abstract}
Background: Pathogenic bacteria cause significant economic damages in agriculture. The detection of such bacteria is considered as a continual interest for plant pathologists to prevent disease dissemination. Pseudomonas syringae pv. syringae is one of the most important bacterial pathogens infecting yield and quality of stone fruits throughout the world. Biochemical assays such as a LOPAT and GATTa are common methods to detect this pathogen. Serological tests and culturing on King's B selective medium also used to isolate this bacterium. Selective media is composed of specific and effective ingredients to inhibit the growth of certain species of microbes in a mixed culture while allowing others to grow. These are used for the growth of only selected microorganisms. King's $\mathrm{B}$ medium can be used as a general medium for the non-selective isolation cultivation and pigment production of Pseudomonas species from foods, cosmetic samples, plants, etc.

Nevertheless, the mentioned methods are not enough accurate to differentiate the strains. On the other hand, PCRbased techniques are sensitive and efficient in detecting plant diseases. However, these techniques are not practicable for those researchers who do not have access to a thermal cycler. We have used loop-mediated isothermal amplification to couple with a target. The amplification of syrD gene using loop and bumper primers can be used to prevent disease dissemination.

Results: The outcome of this investigation indicated more sensitivity of LAMP in comparison to PCR. The direct addition of SYBR Gold in microtube is more sensitive than gel in both LAMP and PCR byproducts so we can eliminate gel electrophoresis, while the LAMP showed high sensitivity and high specificity in comparison to results obtained by cultivation. The described molecular test could detect Pseudomonas syringae pv. syringae type in nearly $1 \mathrm{~h}$, and this is the first time that Lamp molecular detection of Pseudomonas syringae pv. syringae particularly on stone fruits is described and introduced.

Conclusions: The obtained data confirmed that LAMP is a fast, cheap, and high specific method for the rapid detection of Pseudomonas syringae $p v$. syringae to the comparison of PCR and culture.
\end{abstract}

Keywords: SyrD, King's B medium, PCR, LAMP, Molecular diagnosis, Sensitivity, Specificity

\footnotetext{
* Correspondence: drm.mortazavi@goums.ac.ir

${ }^{2}$ Stem Cell Research Center, Golestan University of Medical Sciences, Gorgan,

Iran

${ }^{3}$ Ehya Bone Company, Growth Center, Golestan University of Medical

Sciences, Gorgan, Iran

Full list of author information is available at the end of the article
}

\section{Springer Open}

(c) The Author(s). 2020 Open Access This article is licensed under a Creative Commons Attribution 4.0 International License, which permits use, sharing, adaptation, distribution and reproduction in any medium or format, as long as you give appropriate credit to the original author(s) and the source, provide a link to the Creative Commons licence, and indicate if changes were made. The images or other third party material in this article are included in the article's Creative Commons licence, unless indicated otherwise in a credit line to the material. If material is not included in the article's Creative Commons licence and your intended use is not permitted by statutory regulation or exceeds the permitted use, you will need to obtain permission directly from the copyright holder. To view a copy of this licence, visit http://creativecommons.org/licenses/by/4.0/. 


\section{Background}

Pseudomonas syringae pv. syringae is a bacterial pathogen responsible for twig, diebacks, blossom, leaf or kernel blights, leaf spots [1], and especially bacterial canker, a plant disease characterized by sunken patches of dead bark and small holes in leaves [2-4]. It can lead to diseases in more than 180 plant species such as fruit trees and annual and perennial plants $[5,6]$. Psy damages are determined by on growing region of stone fruits and host plants $[1,7]$. Psy is the most economically important pathogen with many pathovars in 14 species of plant pathogenic Pseudomonas [1].

Isolating these deleterious populations seems important, although screening isolates is considered as a laborious process because of the considerable genotypic and phenotypic diversity demonstrated by this group of bacteria [8]. Although the culture method broadly used to isolate supposed $P$. syringae strains is still presumed a sensitive technique, it causes biases related to the use of phenotypic properties. On the other hand, pathovars from the $P$. syringae group represent considerable diversity in virulence gene repertoires that cannot be used to detect the whole $P$. syringae pathovars [9]. P. marginalis, P. savastanoi, and P. syringae among fluorescent Pseudomonas species have several pathovars that are characterized based on biochemical properties and pathogenicity to host plant species $[1,7]$.

Morphological properties and biochemical assays (e.g., LOPAT and GATTa) [10], serologic tests [11], fatty acid profiling [12], genomic and plasmid DNA analysis [13], and protein analysis [14] are currently used for the detection and identification of Psy and as powerful tools for detection of numerous pathogens besides [15]. Nevertheless, the mentioned methods are not enough accurate to differentiate the strains and pathovars [10]. Pathovars of Pseudomonas which cultivated on KB is usually fluorescent when subjected to ultraviolet light after 24-48 h of incubation $[1,16]$.

Though Psy grows on KB medium and produces green fluorescent pigment, other bacteria belonging to $P$. syringae show positive responses to this non-specific experiment. Hence, this test could not differentiate this pathovar from other pathovars of Pseudomonas [10]. PCR-based techniques are sensitive and efficient in detecting plant diseases. The PCR method has been used to detect genes that participated in the production of coronatine $(C F L)$, secretion of syringomycin $(\operatorname{syr} D)$, and syringomycin synthesis $(\operatorname{syr} B)$ [4].

Rep-PCR has an essential role to analyze the diversity of the pathogen leading to several bacterial diseases of stone fruits and pathovars of $P$. syringae group $[17,18]$. Gasic and colleagues could detect toxin-producing genes, syrB, and $\operatorname{syr} D$ in Psy within stone fruits by RepPCR [19]. Kaluzna et al. identified Pseudomonas syringae pathovars from stone fruit trees using PCR [20]. Therefore, molecular methods must be used for the differentiation of strains [21, 22]. Loop-mediated isothermal amplification (LAMP), as a leading technology uses a heat-resistant strand-displacement DNA polymerase and 4-6 primers targeting definite DNA regions with designed secondary structures formerly [23].

The current study indicates not only loop-mediated isothermal amplification of DNA does not require thermal cycler (unlike PCR) but also can be a valid technique for the detection of Psy with higher sensitivity and specificity. In this method, syrD gene amplification is carried out by Bst DNA Polymerase at a single temperature $\left(60{ }^{\circ} \mathrm{C}\right)$ using loop and bumper primers. SyrD is a conserved pathogenic gene involved in the secretion of the toxin syringomycin in Psy [24]. In 1999, syrD gene detection was done by the Bultreys and Gheysen's method [4]. As syrD conserved among Pseudomonas syringae pathovars, the selection of gene-based LAMP and PCR tests were reasonable [25]. In this research, the identification of the putative gene in Psy by three methods of cultivation, PCR, and LAMP is compared.

\section{Methods}

\section{Bacterial strains collection}

Fifty bacterial canker samples taken from the stem, buds, twigs, and shoots were collected from Azadshahr (Golestan Province, Northern Iran) gardens of stone fruits (peach trees, Prunus persica). Infected samples were stored in plastic bags and restored at $4{ }^{\circ} \mathrm{C}$. Then, a total of 50 bacteria were isolated from 50 infected parts of peach trees.

\section{Bacterial culture}

Fifty samples were divided into two groups: one cultured on selective King's B medium for detection of the strains (Fig. 8). For this purpose, all samples are kept in nutrient broth containing $20 \%$ glycerol at $-85{ }^{\circ} \mathrm{C}$ and cultured on $\mathrm{KB}$ at $25^{\circ} \mathrm{C}$ for $48 \mathrm{~h}$ before usage [16]. After 24-48 h of incubation, fluorescence on KB is observed under UV light [1]. Another group used for genomic DNA extraction carried out using Bioron Ron's Plant DNA Mini Kit (Bioron, Germany).

\section{Genomic DNA extraction}

Genomic DNA was extracted by using Ron's Plant DNA Mini Kit (Bioron, Germany).

\section{SyrD primer pair designing for PCR}

The primer design for the specific identification of putative pathovars of the $P$. syringae group is needed to target distinct and well-defined regions of the genome. SyrD sequence, a 446 bp conserved sequence found in 
the Psy genome [26], was used as a template for primer designing. Primers were analyzed using the NCBI primer blast online tool (https://www.ncbi.nlm.nih.gov/tools/ primer-blast/) for specificity. The sequence of PCR primer pair was shown in Table 1 [27].

\section{$\mathrm{PCR}$ reaction}

To amplify the syrD conserved domain gene, PCR was carried out in total $25 \mu \mathrm{l}$ reaction volume containing $12.5 \mu \mathrm{l}$ AMP fast PCR Master Mix (Takara, Japan), 10.5 $\mu \mathrm{l} \mathrm{H}_{2} \mathrm{O}, 0.5 \mu \mathrm{l}$ each $\mathrm{F}$ and $\mathrm{R}$ primers, and $1 \mu \mathrm{l}(200 \mathrm{ng})$ of genomic DNA. PCR was carried out for 30 cycles at beneath condition: $1 \mathrm{~min}$ initial denaturation at $94{ }^{\circ} \mathrm{C}, 5$ min denaturation at $98{ }^{\circ} \mathrm{C}, 5 \mathrm{~s}$ primer annealing at 55 ${ }^{\circ} \mathrm{C}$, and $10 \mathrm{~s}$ elongation at $72{ }^{\circ} \mathrm{C}$ [28]. PCR amplification reactions were done in a C1000 Touch $^{\text {rm }}$ Thermal Cycler (Bio-Rad, USA) and stained with 1\% agarose gel, and SYBR Gold $1 \mathrm{~kb}$ molecular weight ladder was used.

\section{SyrD primer pairs designing for LAMP}

SyrD-like conserved domain (Gene Bank accession no. KC999805.1) in toxin-producing strains were used for LAMP primer design. The designed primers were synthesized by Bioneer Ltd (South Korea). These primers were synthesized using Primer 3 software. Two primer pairs were checked by NCBI Primer-BLAST online tool (https://www.ncbi.nlm.nih.gov/tools/primer-blast/) to ensure that it is specific for the microorganism. One pair of primers was given from the PCR method. The sequences of the LAMP primer pairs were shown in Table 2. The schematic diagram of the LAMP primer design and detailed locations of primers in the target DNA sequences are shown in (Fig. 1).

\section{LAMP primer amplification}

The concentration of LAMP was carried out in a total $20 \mu \mathrm{l}$ reaction volume containing FIP, BIP, F3 and B3 primers (0.8 $\mu \mathrm{M}$ each), $1.4 \mathrm{mM}$ dNTPs (Fermentas), 0.8 $\mathrm{M}$ betaine (Sigma), $8 \mathrm{mM} \mathrm{MgSO4}$ (Sigma), 8 units of the Bst DNA polymerase large fragment $(8000 \mathrm{U}$, New England Biolabs), $1 \mathrm{ng}$ of target DNA, and $9.92 \mu \mathrm{l}$ of distilled water. In LAMP, the large fragment of Bst DNA polymerase with strand-displacement activity employs loop and bumper primers for DNA fabrications. The mixture was incubated at $60{ }^{\circ} \mathrm{C}$ for $1 \mathrm{~h}$. LAMP products were further observed on $1 \%$ agarose gel for staining

Table 1 Sequences of PCR primers for amplification of the syrD DNA from Psy

\begin{tabular}{lll}
\hline Primer & Length $(\mathrm{bp})$ & Sequence \\
\hline $\mathrm{F}$ & 21 & 5'AAACCAAGCAAGAGAAGAAGG3' \\
$\mathrm{R}$ & 21 & 5'GGCAATACCGAACAGGAACAC3' \\
\hline
\end{tabular}

Table 2 Sequences of LAMP primers for amplification of the syrD DNA from Psy

\begin{tabular}{lll}
\hline Primer & $\begin{array}{l}\text { Length } \\
(\mathrm{bp})\end{array}$ & Sequence \\
\hline F3 & 21 & 5'AAACCAAGCAAGAGAAGAAGG3' \\
B3 & 21 & 5'GGCAATACCGAACAGGAACAC3' \\
FIB & 46 & 5'CAGGGATGGCTGCTCCATAACCAGAC \\
& & CGGGCTCGATAATGCGTCTG3' \\
BIP & 51 & 5'GCAACTCAACGCCACGCTTGATCATGC \\
& & GCCGACTCCACCAGGATCGTTGG3' \\
\hline
\end{tabular}

with SYBR Gold [23]. A $1 \mathrm{~kb}$ molecular weight ladder was used.

\section{Gel staining of PCR and LAMP products}

The amplified PCR products were stained by SYBR Gold on agarose gel [29] (Fig. 2). LAMP uniquely amplifies DNA for producing DNA amplicons with ladder shape behaviors in gel electrophoresis [23] (Fig. 3). Equal dilutions were prepared for both LAMP and PCR products and run on electrophoresis gel for sensitivity comparison of PCR and LAMP products (Fig. 4).

\section{Direct visualization of PCR and LAMP products by SYBR Gold}

To remove electrophoresis step optionally, SYBR Gold was directly added to the PCR and LAMP products in the microtube to be visualized by UV transilluminator (Figs. 5 and 6) [30, 31].

\section{LAMP analysis with different microorganisms}

To determine that the primers are only specified for the stone fruits, the LAMP process was carried out on 10 different microorganisms. The results of these analyses are shown in Fig. 7.

\section{Results \\ Conventional PCR and LAMP detection of syrD gene}

The conventional PCR amplification on syrD using outer primers $\mathrm{F}$ and $\mathrm{R}$ was used to verify whether the correct target was amplified and an expected $446 \mathrm{bp}$ fragment was obtained (Fig. 2).

Two sets of primers were designed for the Pseudomonas syringae $p v$. syringae amplification. To examine whether these sets of primers were able to amplify their target genes, LAMP reactions were conducted and analyzed by agarose gel electrophoresis are shown in (Fig. 3).

\section{The comparison of PCR and LAMP products in terms of sensitivity}

To determine the LOD of the LAMP and PCR assay validation, Two sets of serial dilution of Pseudomonas 


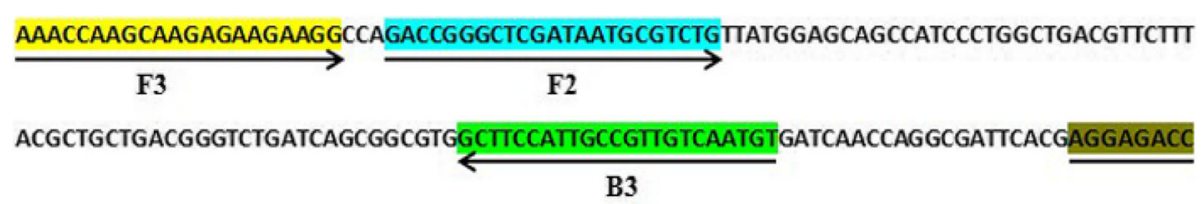

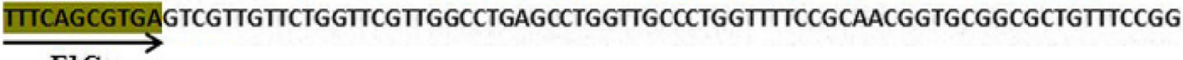
FlC
CCTACGCCAGCATGCACATCATGACCCGTCTGCGCATTGCCCTGTGCCGCAAAATCCTTGGCACACCGCTTGAGGAAGTCG BlC

ACCGCCGCGGTGCGCCGAATGTCCTGACGATGCTCACCAGCGATATTCCGCAACTCAACGCCACGCTTGATCATGCCAAAC

B2

\section{GATCCTGGTGGAGTCGG CGGTGTTCCTGTTCGGTATTGCC}

Fig. 1 Location and partial sequence of loop-mediated isothermal amplification (LAMP) primer set targeting putative syrD sequence of Pseudomonas syringae.pv syringae specific DNA. Locations for two outer (F3 and B3), two inner (FIP [F1C-F2], and BIP [B1c-B2]) primers are indicated in the figure by colors. FIP is a hybrid primer consisting of the F1c sequence and the F2 sequence, and BIP is a hybrid primer consisting of the B1c sequence and the B2 sequence. Arrows indicate the extension direction

syringae pv. syringae. $\left(10,10^{-1}, 10^{-2}, 10^{-3}, 10^{-4}\right)$ from $200 \mathrm{ng}$ genomic DNA for PCR and $\left(10,10^{-1}, 10^{-2}, 10^{-3}\right.$, $10^{-4}, 10^{-5}$ ) from $1 \mathrm{ng}$ of genomic DNA for LAMP were prepared. Diluted templates were amplified using conventional PCR and LAMP. Both products were detected by gel electrophoresis stained with SYBR Gold (Fig. 4).

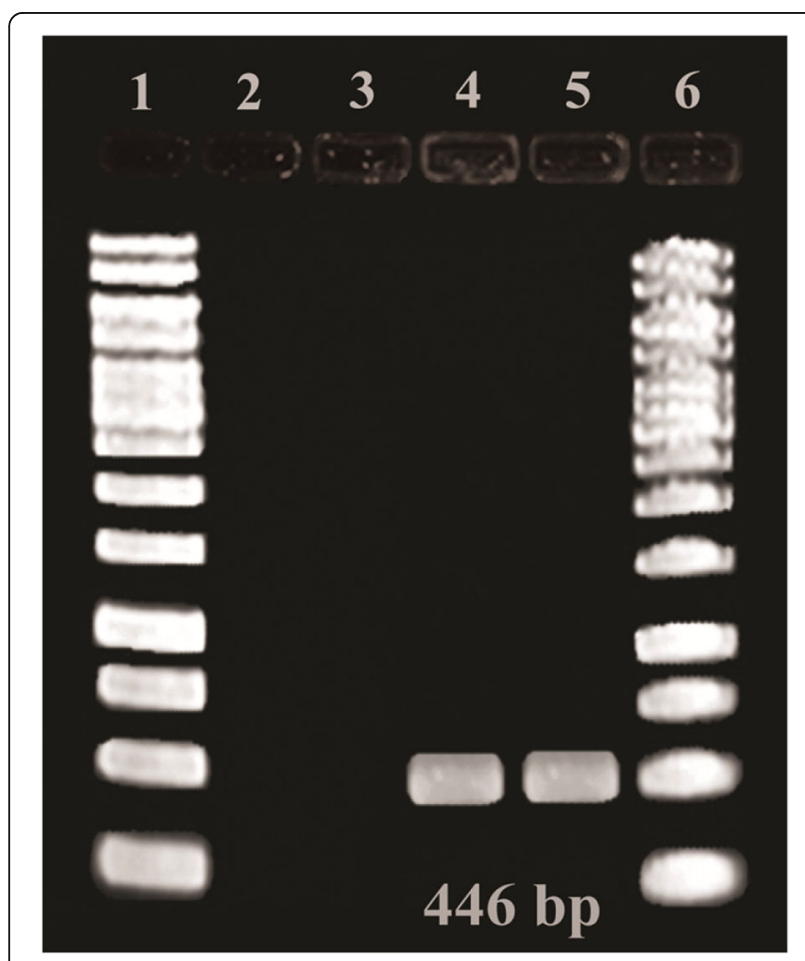

Fig. 2 The results of syrD gene PCR amplification. Lanes 1 and 6, 1 kB DNA ladder (Fermentas); lane 2, blank; lane 3, negative control (Xanthomonas ssp); lanes 4 and 5 show positive responses. A 1 kb molecular weight ladder was used, and all products were stained with SYBR Gold
The comparison of gel-free and electrophoresis-based methods of PCR products in terms of sensitivity To compare the sensitivity of PCR and PCR-free techniques, the same dilutions in the two conditions were considered electrophoresis and then staining in $1 \mathrm{X}$ SYBR

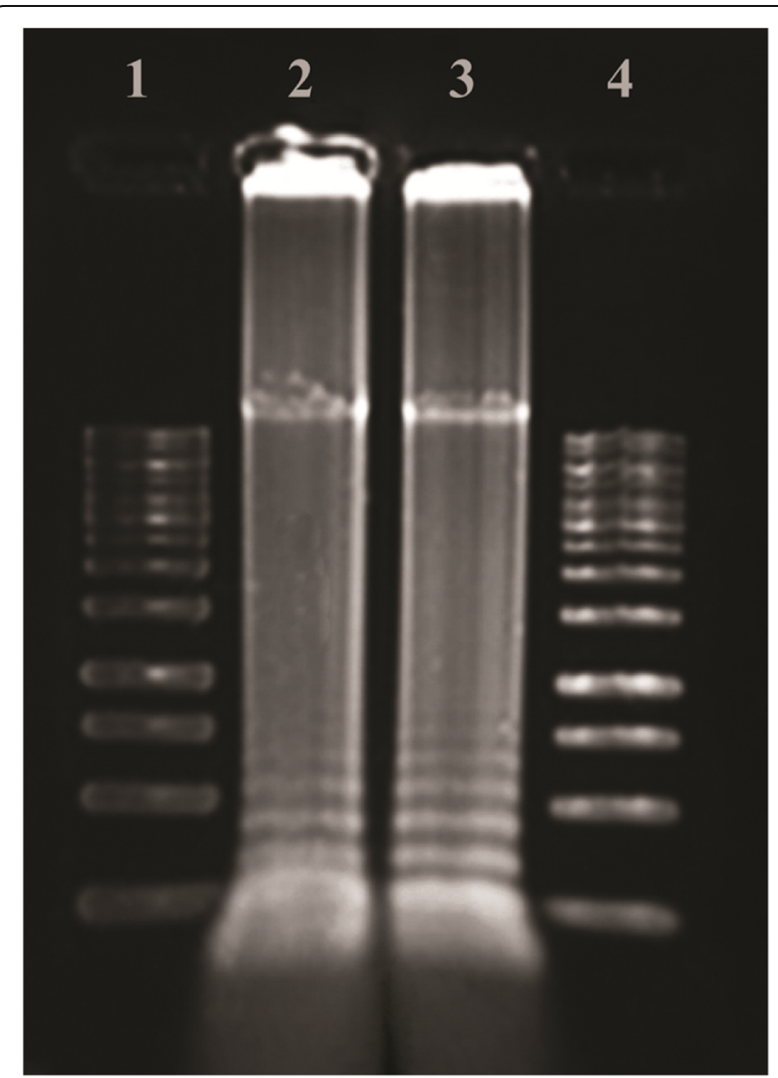

Fig. 3 The results of the syrD gene LAMP. Lanes 1 and 4, 1 kB DNA ladder (Fermentas); lanes 2 and 3 show LAMP results of Pseudomonas syringae pv. syringae with two pairs of primers 


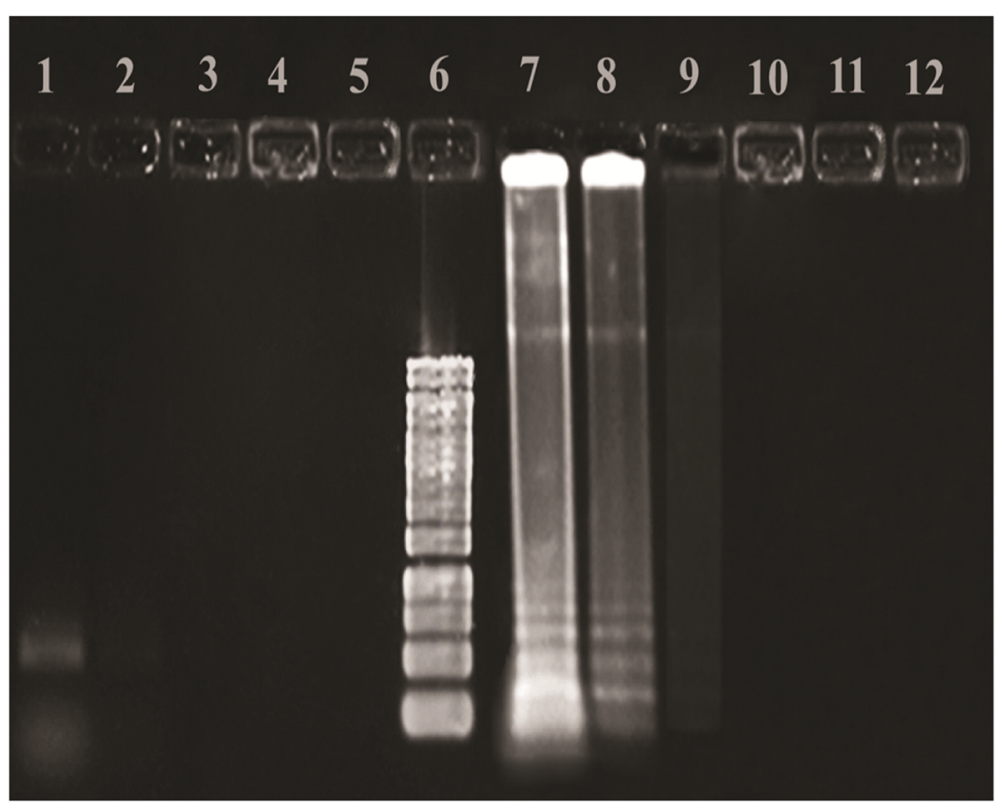

Fig. 4 The comparison of electrophoresis-based methods of PCR and LAMP products in terms of sensitivity. Lane 1, PCR product without dilution $10(200 \mathrm{ng} / \mu \mathrm{l})$; lane 2, PCR product diluted by $10^{-1}(20 \mathrm{ng} / \mu \mathrm{l})$; lane 3, PCR product diluted by $10^{-3}(2 \mathrm{ng} / \mu \mathrm{l})$; lane 4 , PCR product diluted by $10^{-3}$ $(0.2 \mathrm{ng} / \mu \mathrm{ll})$; lane 5, PCR product diluted by $10^{-4}(0.02 \mathrm{ng} / \mu \mathrm{ll})$; and lane $6,1 \mathrm{~kb}$ DNA ladder. Lane 7 , LAMP product without dilution $10(1 \mathrm{ng} / \mu \mathrm{l})$; lane 8, LAMP product diluted by $10^{-1}(0.1 \mathrm{ng} / \mathrm{\mu l})$; lane 9, LAMP product diluted by $10^{-2}(0.01 \mathrm{ng} / \mathrm{\mu l})$; lane 10 , LAMP product diluted by $10^{-3}$ $(0.001 \mathrm{ng} / \mu \mathrm{ll})$; lane 11, LAMP product diluted by $10^{-4}(0.0001 \mathrm{ng} / \mu \mathrm{l})$; and lane $12, \mathrm{LAMP}$ product diluted by $10^{-5}(0.00001 \mathrm{ng} / \mathrm{\mu l})$

Gold, and direct mixing with SYBR Gold 1X (Fig. 5). In part A, only PCR product without the dilution is positive, but in part B, after the direct mixing of PCR products with SYBR Gold, the sensitivity is much higher. So with this method, we can eliminate gel electrophoresis and have faster detection.

The sensitivity of gel-free and gel-based staining of LAMP byproducts

This method is as same as Fig. 5 but compares the sensitivity of LAMP and LAMP-free techniques in the same dilutions in two conditions considered: electrophoresis and then staining in $1 \mathrm{X}$ SYBR Gold (gel-based) and direct mixing with SYBR Gold 1X (gel-free). In part A, LAMP product without the dilution $10(1 \mathrm{ng} / \mu \mathrm{l})$ and $10^{-1}(0.1 \mathrm{ng} / \mu \mathrm{l})$ is positive, but in part $\mathrm{B}$, after direct mixing of LAMP products with SYBR Gold, the $10^{-2}(0.01 \mathrm{ng} / \mu \mathrm{l})$ dilution is positive too, and the sensitivity of the directly mixed is much higher as we said before, and with this method, we can eliminate gel electrophoresis and have faster detection (Fig. 6).

\section{The specificity of designed primers on stone fruits}

As we test only peach sample for comparison of LAMP and culture, we should be sure that the designed primers were only for Pseudomonas syringae pv. syringae of the stone fruit detection. Identification of these primers were tested on 10 different microorganisms showed in Fig. 7.

\section{Bacterial culture on King's B medium}

To determine whether Psy was identified correctly, the suspected samples were cultured on King's B medium at $28{ }^{\circ} \mathrm{C}$. The results indicate that the bacterium has been identified correctly (Fig. 8). After $48-72$ h of incubation, fluorescence on King's medium B was observed under ultraviolet light. Fifteen Pseudomonas syringae strains from 50 samples fluoresced on the KB medium.

\section{Statistical analysis for the comparison of LAMP and culture}

To compare the degree of the specificity and sensitivity of the LAMP process and standard culture, all 50 samples were cultured on King's B medium and the LAMP process was carried out on 50 samples of Psy. The overall results are presented in Table 3 . The results confirmed the high sensitivity and specificity of LAMP assays in comparison to direct culture.

Statistical analysis includes true positives (TP) and true negatives (TN) which were determined by bacterial culture results, with false positives (FP) and false negatives (FN) attributed to findings from the LAMP assays: Sensitivity $=\mathrm{TP} / \mathrm{TP}+\mathrm{FN}$; Specificity $=\mathrm{TN} / \mathrm{TN}+\mathrm{FP}[32]$. 


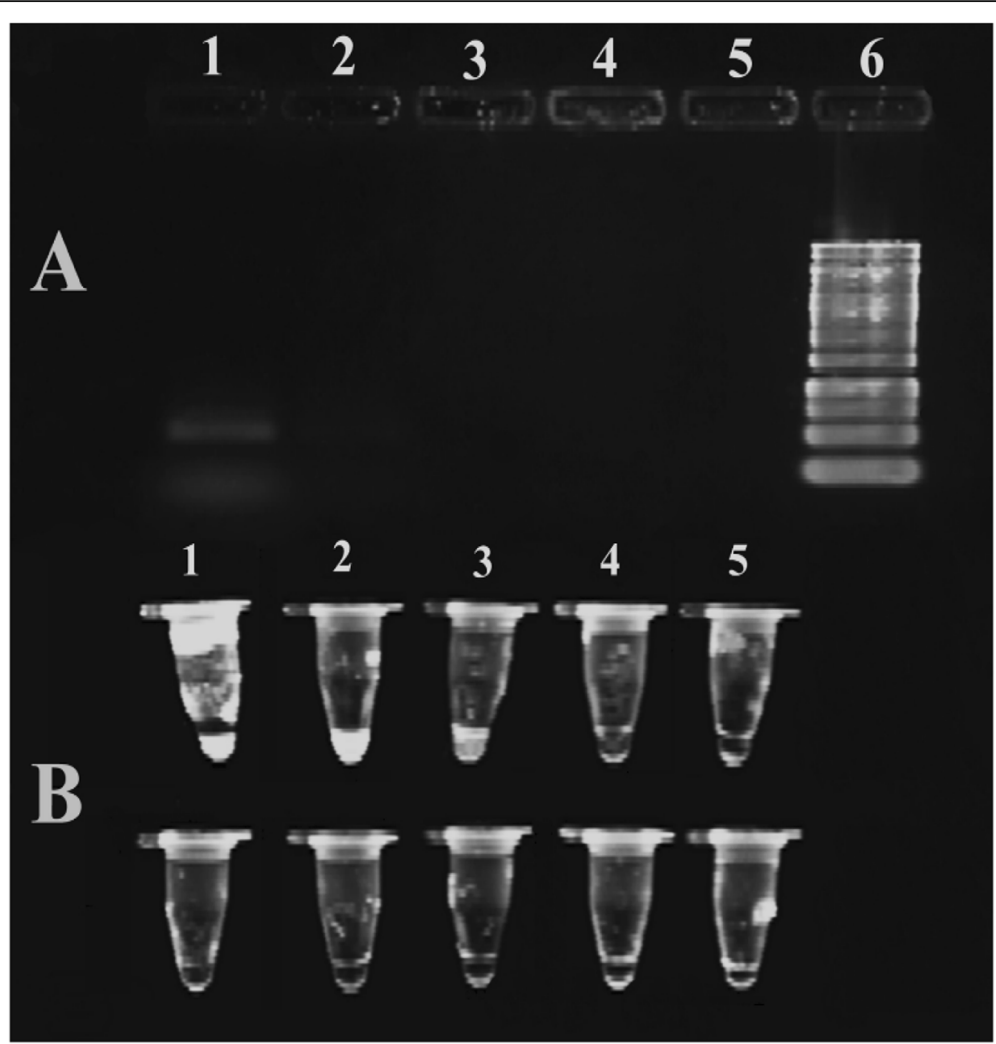

Fig. 5 The comparison of gel-free and gel-based SYBER Gold staining: the upper panel. Part A: lane 1, PCR product without dilution 10 (200 ng/ $\mu \mathrm{ll})$; lane 2, PCR product diluted by $10^{-1}(20 \mathrm{ng} / \mu \mathrm{l})$; lane 3, PCR product diluted by $10^{-2}(2 \mathrm{ng} / \mathrm{\mu l})$; lane 4 , PCR product diluted by $10^{-3}(0.2 \mathrm{ng} / \mu \mathrm{l})$; lane 5, PCR product diluted by $10^{-4}(0.02 \mathrm{ng} / \mu \mathrm{l})$; and lane 6, $1 \mathrm{~kb}$ DNA ladder. Part B: the upper row. Sample 1, a mixture of $10 \mu \mathrm{l} \mathrm{PCR} \mathrm{product}$ $(X)$ and $10 \mu \mathrm{I}$ SYBR Gold. Sample 2, the mixture of $10 \mu \mathrm{I}$ X/10 PCR product and SYBR Gold. Sample 3, the mixture of $10 \mu \mathrm{I}$ X/10 PCR product and SYBR Gold. Sample 4, $10 \mu \mathrm{l}$ X/10000 PCR product and SYBR Gold. Sample 5, $10 \mu \mathrm{l}$ of X100000 PCR product and SYBR Gold. The lower row, $20 \mu \mathrm{l}$ SYBR Gold

\section{Discussion}

The current study showed that isothermal amplification of syrD gene using PCR and LAMP primers along with bacterial cultivation on King's B medium can be used to detect and identify Psy cultivation as an available and effective isolation method which can identify low concentrations of this pathovar from environmental infected samples [33]. The proficiency of the operator was used to identify and isolate the intended pathovar based on fluorescence and colony morphology. The colonies of Psy grew on King's B medium. As Shaad's work [1], after 48-72 h of incubation, fluorescence on King's B medium was observed under UV light. Fifteen Psy pathovars (in 15 separate plates) from 50 samples were fluorescent on the KB medium (Fig. 8).

Since some other pathovars of Pseudomonas syringae also show positive responses to KB medium and produce green fluorescent pigment and, finally, lead to biases related to the use of phenotypic properties, it is not considered as a specific test to differentiate Psy from other pathovars of Pseudomonas [9, 10]. The LAMP technology is utilized in diagnostic laboratories for the rapid identification of several pathogenic bacteria in blood samples [34, 35]. However, no one has been employed in its application for the detection of Psy. The LAMP reaction itself takes place within $60 \mathrm{~min}$, while only $3 \mathrm{~h}$ is required for perfect identification of cultivated cells [36]. The selection of third gene-based LAMP and PCR tests were reasonable because this gene should be conserved in all Pseudomonas syringae strains [25]. The presence of the $s y r D$ gene can be proved by PCR and LAMP tests specifically [37].

The specificity of the LAMP as the isothermal method in $60{ }^{\circ} \mathrm{C}$ and PCR test performed with an annealing temperature of $55{ }^{\circ} \mathrm{C}$ is shown in Fig. 2 and 3. In the LAMP section, lanes 2 and 3 indicate LAMP results of Psy with two pairs of primers. In the PCR section, lanes 4 and 5 show positive responses. Lane 3 , as a negative control (Xanthomonas ssp). It means the related primer was specific for Psy. Both PCR and LAMP detection of the $\operatorname{syr} D$ gene were positive. Amplification of a unique DNA product in the $s y r D$ PCR showed the high specificity of the designed syrD gene primers. In 1999, Bultreys and Gheysen carried out a PCR test with designed 


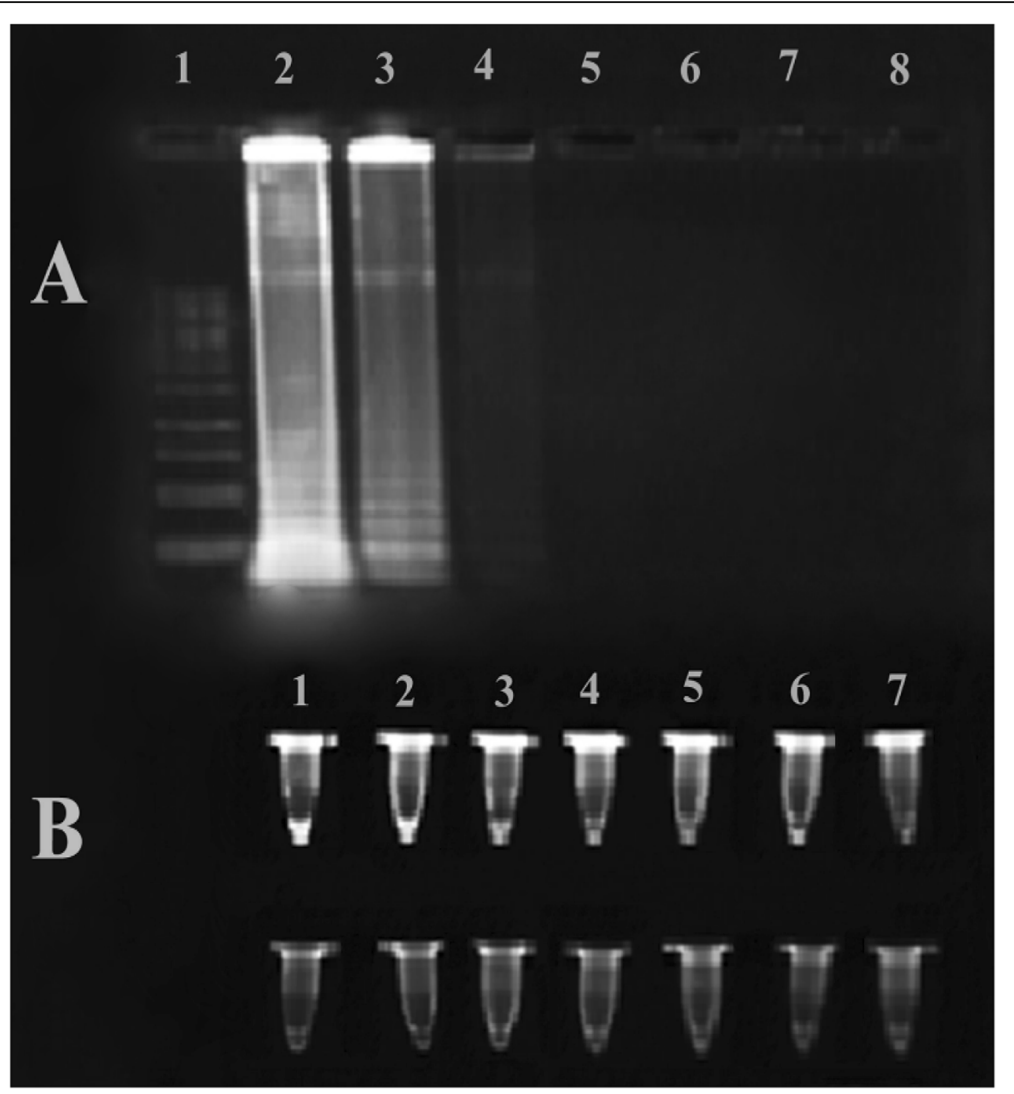

Fig. 6 The comparison of gel-free and gel-based SYBER Gold staining: the upper panel. Part A: lane 1, 1 kb DNA ladder; lane 2, LAMP product without dilution 10 (1 ng/ $/ \mathrm{ll})$; lane 3, LAMP product diluted by $10^{-1}(0.1 \mathrm{ng} / \mathrm{\mu l})$; lane 4, LAMP product diluted by $10^{-2}(0.01 \mathrm{ng} / \mathrm{\mu l})$; lane 5, LAMP product diluted by $10^{-3}(0.001 \mathrm{ng} / \mu \mathrm{l})$; lane 6, LAMP product diluted by $10^{-4}(0.0001 \mathrm{ng} / \mathrm{\mu l})$; and lane 7, LAMP product diluted by $10^{-5}(0.00001$ $\mathrm{ng} / \mu \mathrm{ll}$ ). Part B: the upper row. Sample 1, a mixture of $10 \mu \mathrm{l}$ LAMP product $(X)$ and $10 \mu \mathrm{l}$ SYBR Gold. Sample 2, a mixture of $10 \mu \mathrm{l}$ 1/10 LAMP product and SYBR Gold 3. A mixture of $10 \mu \mathrm{l}$ 1/100 LAMP product and SYBR Gold. Sample 3: a mixture of $10 \mu \mathrm{l}$ 1/1000 LAMP product and SYBR Gold. Sample 4, $10 \mu \mathrm{l}$ 1/10000 LAMP product and SYBR Gold. Sample 5, $10 \mu \mathrm{l}$ of 1/100000 LAMP product. Sample 6, $10 \mu \mathrm{l}$ of 1/1000000 LAMP product and SYBR Gold. Sample 7, $10 \mu$ l of 1/1000000 LAMP product. Part B: the lower row, $20 \mu$ I SYBR Gold

primers for amplification of a $1040 \mathrm{bp}$ fragment in the syrD gene coding sequence leading to efficient detection of the desired gene among related lipodepsipeptideproducing pathovars [18].

Guilbaud and colleagues in 2016 could efficiently perform isolation and identification of Pseudomonas syringae among the whole $P$. syringae group by using a method combining the PCR (named Pseudomonas syringae-specific polymerase chain reaction (Psy-PCR) detection and bacteria cultivation) [26]. Vincente et al. were discriminate Pseudomonas syringae isolates from sweet and wild cherry using rep-PCR [38]. Figure 4 contained the comparison of electrophoresis-based methods of PCR and LAMP products in terms of sensitivity. Similar dilution was prepared for both LAMP and PCR products. Lane 1 showed PCR product without dilution 10 (200 $\mathrm{ng} / \mu \mathrm{l})$, and lanes 7 and 8 showed LAMP product diluted by $10(1 \mathrm{ng} / \mu \mathrm{l})$ and $10^{-1}(0.1 \mathrm{ng} / \mu \mathrm{l})$, respectively.

The sensitivity of the lamp technique is 10 times higher than the PCR between these two electrophoresis- based methods. Figure 5 represented the results of gelfree and electrophoresis-based methods of PCR products in terms of sensitivity. In both parts, the same serial dilutions were prepared. In section $\mathrm{A}$, only the first lane got a positive answer, but in section $\mathrm{B}$, the positive answer showed on the third microtube.

The results indicated that the direct addition of SYBR Gold with PCR products in microtubes was 100 times more sensitive than electrophoresis in the direct visualization. Figure 6 contained the sensitivity of gelfree and gel-based staining of LAMP byproducts. In part A, lanes 2 and 3 showed the LAMP ladder-like band, and in part $\mathrm{B}$, the positive answer showed in the third microtube. The results indicated that the direct addition of SYBR Gold with LAMP products in microtubes was 10 times more sensitive than electrophoresis in the direct visualization. All 15 colonies growing on 15 plates of $\mathrm{KB}$ medium gave positive in LAMP. One hundred percent of the Psy colonies on KB medium were detected by the LAMP technique. The specificity of LAMP 


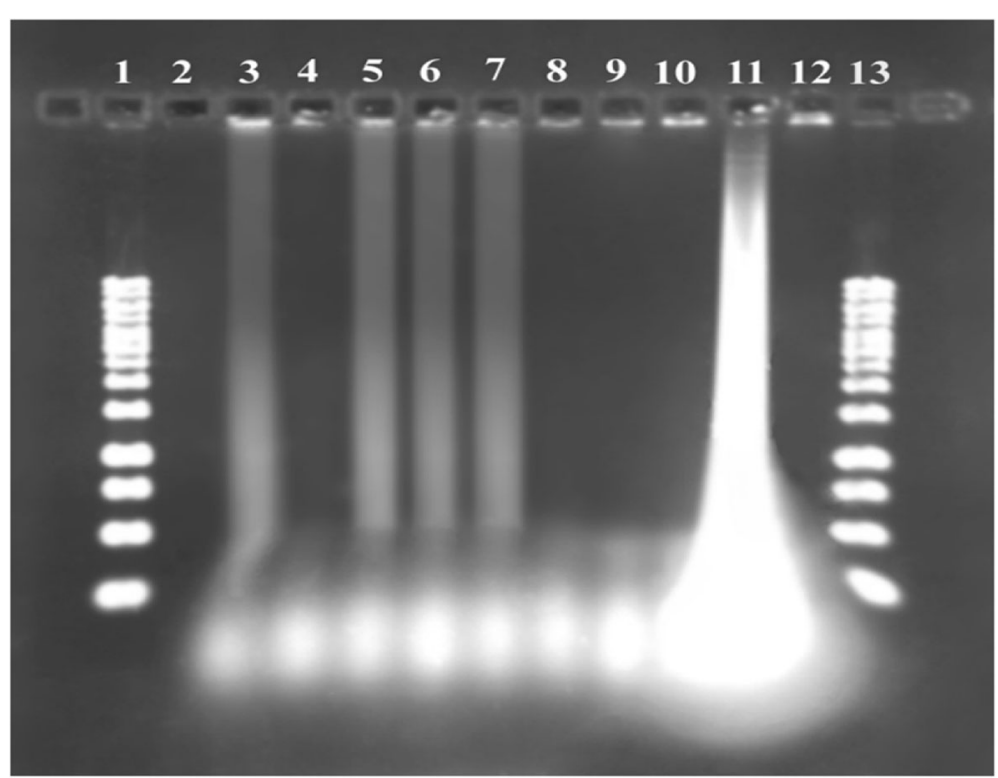

Fig. 7 LAMP process on different microorganisms in terms of specificity of the designed primers that only detect stone fruits: lanes 1 and 13,1 kb DNA ladder; lane 2, blank; lane 3, cherry, lane 4, tomato; lane 5, apricot; lane 6, almond; lane 7, peach; lane 8, olive; lanes 9 and 10, positive controls (Xanthomonas campestris ssp); lane 11, plum; and lane 12, negative control (Brenneria spp)

primer pairs by testing on different kinds of stone fruits was shown in Fig. 7.

Based on Table 3, different results mean the LAMP technique outperforms the culturing method in terms of sensitivity and specificity. Despite reliability, specificity, and benefits of more speed, simplicity and sensitivity, in comparison with other methods [37, 39], in similar work (1998), Sorenson suggested that amplification of PCR with $s y r D$-based primers, as revealed by cyclic lipodepsinonapeptide production or with southern blot analysis,

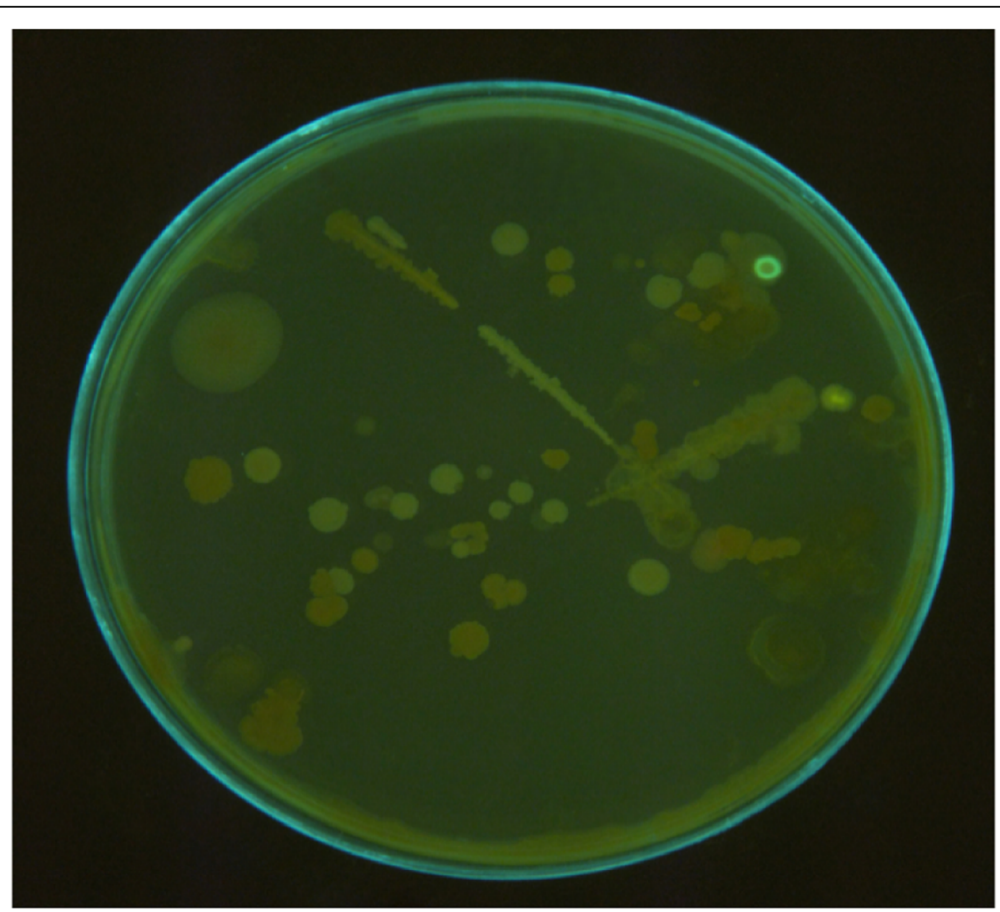

Fig. 8 Bacterial culture on King's B medium (1 plate of 50 samples). After 48-72 h of incubation, fluorescence on King's medium B was observed under UV light. Fluorescence colonies showed Pseudomonas syringae pv. syringae has grown on this medium 
Table 3 The comparison of LAMP assays with direct bacterial cultivations

\begin{tabular}{llllll}
\hline \multirow{2}{*}{ Tests and results } & \multicolumn{2}{l}{ Culture } & & Sensitivity & Specificity \\
\cline { 3 - 4 } & & Pos & Neg & & \\
\hline LAMP & Pos & 15 & 0 & $100 \%$ & $100 \%$ \\
& Neg & 0 & 35 & & \\
\hline
\end{tabular}

did not always associate with the existence of the $\operatorname{syr} D$ gene $[27,40]$. The comparison of Figs. 5 and 6 direct visualization shows that the sensitivity of loop-mediated isothermal amplification technique in detecting Psy is more than that of PCR. Moreover, the LAMP method is more rapid than PCR-based techniques, needs less time in comparison to PCR, and does not need any thermal cycler and expert staff.

PCR is used in numerous studies to identify pathogenic microorganisms. Amplification of $s y r D$ gene using PCR for identification of phytopathogenic strains of $P$. syringae $p v$. syringae has been already reported [4]. Kaluzna and colleagues studied characterization and genetic diversity of Pseudomonas syringae isolated from stone fruits and hazelnut using repetitive-PCR and MLST [21]. Gasic and colleagues could detect toxinproducing genes, $\operatorname{syr} B$, and $\operatorname{syr} D$ in Psy within stone fruits by Rep-PCR [19]. LAMP primers have been reported to be able to detect other species of Pseudomonas syringae pv. phaseolicola [40].

Kumar Ghosh and colleagues using LAMP for the detection of Candidatus liberibacter in citrus and psyllid vector, Diaphorina citri Kuwayama asiaticus, report it as a good technique for early detection [41]. Keizerweerd et al. showed that LAMP and real-time PCR had the same sensitivity in $0.1 \mathrm{ng}$ for the detection of Puccinia kuehnii and reported that LAMP was specific and rapid [42]. Herrera-Vasquez and colleagues used LAMP for the detection of Begomovirus species infecting tomato; they report the same sensitivity between LAMP and PCR, but mention that LAMP is a rapid specific and cheap method [43]. LAMP isothermal amplification has already been used to detect Pseudomonas syringae $p v$. lachrymans in cucumber leaves and was found to be a reliable and sensitive method [44]. LAMP assay showed to be a powerful tool for the detection of $\mathrm{P}$. aeruginosa strains, as well [45]. Sun et al. were reported that the LAMP diagnostic assay contributes to the rapid and accurate detection of soft-rot disease in Amorphophallus konjac at an early stage [46]. LAMP-based detection showed to be more sensitive than PCR in detecting Phytophthora hibernalis, P. syringae, and P. cambivora [47]. The comparison of LAMP assays with direct bacterial cultivation showed high sensitivity and high specificity. When comparing the efficiency of the three mentioned techniques, LAMP was better than the PCR-based and culturing methods for its higher respective sensitivity and specificity. Hence, The LAMP test could work as a reliable and prompt tool to detect and identify with considerable applications in environmental and agricultural sciences. As shown in this study, syrD amplifying LAMP primers are efficient in isothermal gene amplification as well and can be used to detect Psy.

\section{Conclusions}

Pathogen detection, identification, and quantification are important in plant disease control and must be accessible in all regions to ensure sustainable crop production and food safety to our knowledge. This study is the first to report on the comparison of different PCR-based assays culture and the LAMP technique for the detection of Pseudomonas syringae $p v$. syringae that particularly damaged stone fruits.

The current study described a novel molecular detection of Pseudomonas syringae pv. syringae that particularly damaged stone fruits. LAMP is a fast, highly specific and cheap tool for early molecular detection of Psy on stone fruits. The method does not need a thermal cycler; it will be practical for a larger number of researchers. LAMP techniques can eliminate biases for further classification and characterization of putative colonies.

\section{Abbreviations}

B3: Backward outer primer; BIP: Backward inner primer; CFL: Corono facate ligase; F primer: Forward primer; F3: Forward outer primer; FIP: Forward inner primer; FN: False negatives; FP: False positives; GATTa: Gelatin liquefaction, aesculin hydrolysis, tyrosinase activity, tartrate utilization; KB: King's B; LAMP: Loop-mediated isothermal amplification; LOD: Limit of detection; LOPAT: Levan production, oxidase production, pectinolytic activity, arginine dihydrolase production, tobacco hypersensibility; MLST: Multilocus sequence typing; Neg: Negative; PCR: Polymerase chain reaction; Pos: Positive; Psy: Pseudomonas syringae pv. syringae; R primer: Reverse primer; RepPCR: Repetitive polymerase chain reaction; syrB: Syringomycin B; syrD: Syringomycin D; TN: True negatives; TP: True positives; UV: Ultraviolet

\section{Acknowledgments}

Special thanks to Ehya Bone Company, Growth Center

\section{Authors' contributions}

MMMR designed the experiments. RG is performed the experiments. MMMR and $R G$ analyzed the data. RG and MMMR wrote the paper. All authors read and approved the final manuscript.

\section{Funding}

Not applicable.

\section{Availability of data and materials}

The datasets used and/(or) analyzed during the current study are available from the corresponding author on reasonable request.

Ethics approval and consent to participate

Not applicable to this section.

Consent for publication

The authors declare that they have no conflict of interest.

Competing interests

The authors declare that they have no competing interests. 


\section{Author details}

'Department of Agriculture, Damghan Islamic Azad University, Damghan, Iran. ${ }^{2}$ Stem Cell Research Center, Golestan University of Medical Sciences, Gorgan, Iran. ${ }^{3}$ Ehya Bone Company, Growth Center, Golestan University of Medical Sciences, Gorgan, Iran. ${ }^{4}$ Transmission Electron Microscope Lab, Biomedical Technology Wing, SCTIMSTs, Trivandrum, India.

\section{Received: 28 April 2020 Accepted: 20 August 2020}

\section{Published online: 02 October 2020}

\section{References}

1. Schaad NW, Jones JB, Chun W (2001) Laboratory guide for identification of plant pathogenic bacteria. USA: American Phytopathological Society Press

2. Gross DC (1991) Molecular and genetic analysis of toxin production by pathovars of Pseudomonas syringae. Annu Rev Phytopathol 29(1):247-278

3. Ram V, Bhardwaj $L$ (2004) Stone fruit diseases and their management in diseases of fruits and vegetables: Volume 2. Springer, p. 485-510

4. Bultreys A, Gheysen I (1999) Biological and molecular detection of toxic lipodepsipeptide-producing Pseudomonas syringae strains and PCR identification in plants. Appl Environ Microbiol 65(5):1904-1909

5. Little E, Bostock R, Kirkpatrick B (1998) Genetic characterization of Pseudomonas syringae pv. syringae strains from stone fruits in California. Appl Environ Microbiol 64(10):3818-3823

6. Agrios G (2005) Plant pathology. Elsevier Academic Press, Burlington, Ma. USA, pp 79-103

7. Young JM, Saddler GS, Takikawa Y, Boer SH, Vauterin L et al (1996) Names of plant pathogenic bacteria 1864-1995. Rev Plant Pathol 75(9):721-763

8. Berge O, Monteil CL, Bartoli C, Chandeysson Ch, Guilbaud C, Sands DC (2014) A user's guide to a data base of the diversity of Pseudomona syringae and its application to classifying strains in this phylogenetic complex. PloS one 9(9):e105547

9. Baltrus DA, Nishimura MT, Romanchuk A, Chang JH, Shahid Mukhtar M et al (2011) Dynamic evolution of pathogenicity revealed by sequencing and comparative genomics of 19 Pseudomonas syringae isolates. PLoS Pathog 7(7):e1002132

10. Bultreys A, Kaluzna M (2010) Bacterial cankers caused by Pseudomonas syringae on stone fruit species with special emphasis on the pathovars syringae and morsprunorum race 1 and race 2. J Plant Pathol:S21-S33

11. Benedict AA, Alvarez AM, Berestecky J, Imanaka W, Mizumoto CY et al (1989) Pathovar-specific monoclonal antibodies for Xanthomonas campestris pv. oryzae and for Xanthomonas campestris pv. oryzicola. Phytopathology 79(3):322-328

12. Stead D Evaluation of cellular fatty acid profiles for rapid identification of plant pathogenic bacteria. in proceedings 7th International Conference on Plant Pathogenic Bacteria, Budapest. 1990

13. Berthier Y, Verdier V, Guesdon JL, Chevrier D, Denis JB et al (1993) Characterization of Xanthomonas campestris pathovars by rRNA gene restriction patterns. Appl Environ Microbiol 59(3):851-859

14. Van Zyl E, Steyn P (1990) Differentiation of phytopathogenic Pseudomonas and Xanthomonas species and pathovars by numerical taxonomy and protein gel electrophoregrams. Syst Appl Microbiol 13(1):60-71

15. Henson JM, French R (1993) The polymerase chain reaction and plant disease diagnosis. Annu Rev Phytopathol 31(1):81-109

16. King EO, Ward MK, Raney DE (1954) Two simple media for the demonstration of pyocyanin and fluorescin. J Lab Clin Med 44(2):301-307

17. Ménard M, Sutra L, Luisetti K, Prunie JP, Gardan L (2003) Pseudomonas syringae pv. avii (pv. nov.), the causal agent of bacterial canker of wild cherries (Prunus avium) in France. Eur J Plant Pathol 109(6):565-576

18. Marques AS, Corbière R, Gardan R, Tourte C, Manceau Ch et al (2000) Multiphasic approach for the identification of the different classification levels of Pseudomonas savastanoi pv. phaseolicola. Eur J Plant Pathol 106(8): 715-734

19. Gašić K, Prokić A, Ivanovic MM, Kuzmanović N, Obradović A (2012) Differentiation of Pseudomonas syringae pathovars originating from stone fruits. Pestic Fitomed 27(3):219-229

20. Kaluzna M, Puławska J, Sobiczewski $P$ (2010) The use of PCR melting profile for typing of Pseudomonas syringae isolates from stone fruit trees. Eur J Plant Pathol 126(4):437-443

21. Kaluzna M, Ferrante P, Sobiczewski P, Scortichini M (2010) Characterization and genetic diversity of Pseudomonas syringae from stone fruits and hazelnut using repetitive-PCR and MLST. J Plant Pathol p.781-787
22. Konavko D, Morocko-Bicevska I, Bankina B (2014) Pseudomonas syringae as important pathogen of fruit trees with emphasis on plum and cherry. Res Rural Devel p.19-25

23. Notomi T, Okayama H, Masubuchi H, Yonekawa T, Watanabe K et al (2000) Loop-mediated isothermal amplification of DNA. Nucleic Acids Res 28(12): e63-e63

24. Quigley NB, Mo YY, Gross DC (1993) SyrD is required for syringomycin production by Pseudomonas syringae pathovar syringae and is related to a family of ATP-binding secretion proteins. Mol Microbiol 9(4):787-801

25. Grgurina I, Gross DC, Lacobellis NS, Paola Lavermicocca P, Takemoto JY, Benincasa M (1996) Phytotoxin production by Pseudomonas syringae pv. syringae: Syringopeptin production by syr mutants defective in biosynthesis or secretion of syringomycin. FEMS Microbiol Lett 138(1):35-39

26. Guilbaud C, Morris CE, Barakat M, Ortet P, Berge O (2016) Isolation and identification of Pseudomonas syringae facilitated by a PCR targeting the whole P. syringae group. FEMS Microbiol Ecol 92(1)

27. Sorensen KN, Kim KH, Takemoto JY (1998) PCR detection of cyclic lipodepsinonapeptide-producing Pseudomonas syringae pv. syringae and similarity of strains. Appl Environ Microbiol 64(1):226-230

28. Mullis KB (1990) The unusual origin of the polymerase chain reaction. Sci Am 262(4):56-65

29. Lee PY, Costumbrado J, Hsu C, Kim YM (2012) Agarose gel electrophoresis for the separation of DNA fragments. JoVE (62): p. e3923

30. Ibarra-Meneses AV, Cruz I, Chicharro C, Sánchez C, Biéler B et al (2018) Evaluation of fluorimetry and direct visualization to interpret results of a loop-mediated isothermal amplification kit to detect Leishmania DNA. Parasit Vectors 11(1):1-9

31. Tuma RS, Beaudet MP, Jin X, Jones $L$, Cheung CY et al (1999) Characterization of SYBR Gold nucleic acid gel stain: a dye optimized for use with 300-nm ultraviolet transilluminators. Anal Biochem 268(2):278-288

32. Moskowitz CS, Pepe MS (2006) Comparing the predictive values of diagnostic tests: sample size and analysis for paired study designs. Clin Trials 3(3):272-279

33. Morris CE, Sands DC, Vinatzer BA, Glaux C, Guilbaud C et al (2008) The life history of the plant pathogen Pseudomonas syringae is linked to the water cycle. The ISME J 2(3):321-334

34. Iwamoto T, Sonobe T, Hayashi K (2003) Loop-mediated isotherma amplification for direct detection of Mycobacterium tuberculosis complex, $M$. avium, and $M$. intracellulare in sputum samples. J Clin Microbiol 41 (6): 2616-2622

35. Misawa Y, Saito R, Moriya K, Koike K, Yoshida A (2007) Application of loopmediated isothermal amplification technique to rapid and direct detection of methicillin-resistant Staphylococcus aureus (MRSA) in blood cultures. J Infect Chemother 13(3):134-140

36. Kubota R, Vine BG, Alvarez AM, Jenkins DM (2008) Detection of Ralstonia solanacearum by loop-mediated isothermal amplification. Phytopathology 98(9):1045-1051

37. Bereswill S, Bugert P, Völksch B, Ullrich M, Bender CL, Geider K (1994) Identification and relatedness of coronatine-producing Pseudomonas syringae pathovars by PCR analysis and sequence determination of the amplification products. Appl Environ Microbiol 60(8):2924-2930

38. Vicente JG, Roberts SJ (2007) Discrimination of Pseudomonas syringae isolates from sweet and wild cherry using rep-PCR. Eur J of Plant Pathol 117(4):383-392

39. Raaijmakers JM, Weller DM, Thomashow LS (1997) Frequency of antibioticproducing Pseudomonas spp. in natural environments. Appl Environ Microbiol 63(3):881-887

40. Li X, Nie J, Ward L, Madani M, Hsiang T, Zhao Y, De Boer SH (2009) Comparative genomics-guided loop-mediated isothermal amplification for characterization of Pseudomonas syringae pv. phaseolicola. J Appl Microbio 107(3):717-726

41. Ghosh DK, Bhose S, Warghane A, Motghare M, Kumar Sharma A et al (2016) Loop-mediated isothermal amplification (LAMP) based method for rapid and sensitive detection of 'Candidatus Liberibacter asiaticus' in citrus and the psyllid vector, Diaphorina citri Kuwayama. J Plant Biochem Biotech 25(2): 219-223

42. Chandra A, Keizerweerd AT, Grisham MP (2016) Detection of Puccinia kuehnii causing sugarcane orange rust with a loop-mediated isothermal amplification-based assay. Mol Biotechnol 58(3):188-196

43. Herrera-Vásquez JA, Puchades AV, Elvira-González L, Jaén-Sanjur JN, Carpino C et al (2018) Fast detection by loop-mediated isothermal amplification 
(LAMP) of the three begomovirus species infecting tomato in Panama. Eur J Plant Pathol 151(1):243-250

44. Meng XL, Xie XW, Shi YX, Chai AL, Ma ZH, Li BJ (2017) Evaluation of a loopmediated isothermal amplification assay based on $h r p Z$ gene for rapid detection and identification of Pseudomonas syringae pv. lachrymans in cucumber leaves. J Appl Microbiol 122(2):441-449

45. Zhao X, Wang L, Li Y, Xu Z, Li L, He X (2011) Development and application of a loop-mediated isothermal amplification method on rapid detection of Pseudomonas aeruginosa strains. World I of Microbiol Biotechnol 27(1):181184

46. Sun M, Liu H, Huang J, Peng J, Fei F et al (2019) A loop-mediated isothermal amplification assay for rapid detection of Pectobacterium aroidearum that Causes Soft Rot in Konjac. Int J Mol Sci 20(8): p. 1937

47. Li GR, Huang GM, Zhu LH, Lv D, Cao B et al (2019) Loop-mediated isothermal amplification (LAMP) detection of Phytophthora hibernalis, $P$. syringae and P. cambivora. J Plant Pathol 101(1):51-57

\section{Publisher's Note}

Springer Nature remains neutral with regard to jurisdictional claims in published maps and institutional affiliations.

\section{Submit your manuscript to a SpringerOpen ${ }^{\circ}$ journal and benefit from:}

- Convenient online submission

- Rigorous peer review

- Open access: articles freely available online

High visibility within the field

- Retaining the copyright to your article

Submit your next manuscript at $\boldsymbol{\nabla}$ springeropen.com 